\title{
The Predictors of Early Mortality in Geriatric Patients who Hospitalized to the Intensive Care Unit with Aspiration Pneumonia
}

\section{Aspirasyon Pnömonisi ile Yoğun Bakım Ünitesine Yatan Geriatrik Hastalarda Erken Mortalite Belirteçleri}

\author{
(D) Fulya Çiyiltepe1, (D)Asu Özgültekin² \\ 'University of Health Sciences, İstanbul Kartal Dr. Lütfi Kırdar City Hospital, Department of Anesthesiology and Reanimation, Istanbul, Turkey \\ 2University of Health Sciences, İstanbul Haydarpaşa Numune Training and Research Hospital, Department of Anesthesiology and \\ Reanimation, Istanbul, Turkey
}

\begin{abstract}
Aim: In the geriatric group, aspiration pneumonia is one of the most common causes of Intensive Care Unit admission. Multiple comorbidities related with systemic diseases, as well as dementia, fraility and difficulty in swallowing or protecting the airway may all contribute the development of the AP in the geriatric age. Furthermore, many other variables may influence the outcome of this patient group. In this study, it is aimed to determine the parameters that may have an effect on the intensive care mortality. Material and Method: 221 patients aged $\geq 80$ years who were admitted to the third level ICU with the diagnosis of aspiration pneumonia were retrospectively analyzed. They were divided into two groups according to the 28-day outcome (survivednonsurvived). The admission levels of arterial blood $\mathrm{Ph}$ and $\mathrm{pCO}_{2}$ and lactate, blood urea, creatinine, potassium (K) and sodium (Na) levels, APACHE II, Glaskow Coma Scale (GCS), modified shock index (MSI) and the aspiration pneumonia's source ( communityacquired aspiration pneumonia (CA-AP) or healthcare-associated aspiration pneumonia (HCA-AP) )were recorded.The effects of these variables on 28-day mortality were analyzed.

Results: The presence of HCA-AP, GCS and APACHEll scores were found to be significantly correlated between the two groups. ROC analysis were done for those variables and cutoff points werecalculated. Logistic regression analysis showed that, APACHE II $(>22.5, A \cup C: 0.812, P=0.00)$, GCS $(<9, A \cup C: 0.730, G=0.00)$ and the presence of HCA-AP as the most relivient predictors of mortality.

Conclusion: Although many variables are significant in predicting the first 28 days of mortality in ICU admission of geriatric patients with aspiration pneumonia, the presence of HCA-AP, high hospitalization APACHE II score and low GCS score were significant independent variables in predicting intensive care mortality.
\end{abstract}

Keywords: Aspiration pneumonia, geriatrics, mortality predictors, intensive care units, healthcare-associated aspiration pneumonia

\begin{abstract}
Öz
Amaç: Geriatrik grupta aspirasyon pnömonisi en sık Yoğun Bakıma yatış nedenlerinden biridir. Sistemik hastalıklarla ilişkili çoklu komorbiditelerin yanı sıra demans, kırılganlık ve yutma veya hava yolunu koruma güçlüğü geriatrik yaşta aspirasyon pnömonisinin oluşumuna katkıda bulunabilir. Ayrıca, diğer birçok değişken bu hasta grubunun sonucunu etkileyebilir. Bu çalışmada yoğun bakım mortalitesine etkisi olabilecek parametrelerin belirlenmesi amaçlanmıştır.
\end{abstract}

Materyal ve Metod: Aspirasyon pnömonisi tanısı ile üçüncü basamak yoğun bakım ünitesine yatırılan 80 yaş ve üzeri 221 hasta retrospektif olarak incelendi. 28 günlük sonuçlara göre iki gruba ayrıldılar (hayatta kalanlar ve hayatta kalmayanlar). Arteriyel kan $\mathrm{Ph}$ ve $\mathrm{pCO}_{2}$ ve laktat, kan üre, kreatinin, potasyum (K) ve sodyum $(\mathrm{Na})$ seviyeleri, APACHE II, Glaskow Koma Ölçeği (GCS), modifiye şok indeksi (MSI) ve aspirasyon pnömonisinin kaynağı ( toplum kökenli aspirasyon pnömonisi (CAAP) veya sağlık hizmeti ile ilişkili aspirasyon pnömonisi (HCA-AP)) kaydedildi. Bu değişkenlerin 28 günlük mortalite üzerindeki etkileri analiz edildi.

Bulgular: HCA-AP, GCS ve APACHEll skorlarının varlığı iki grup arasında anlamlı olarak ilişkili bulundu. Bu değişkenler için ROC analizi yapıldı ve kesme noktaları hesaplandı. Lojistik regresyon analizi, APACHEll (>22.5, AUC:0.812,P=0.00) ve GCS'nin ( $<9, A \cup C: 0.730, P=0.00)$ HCA-AP varlığı ilebirlikte mortalitenin en belirgin bağımlı belirleyicileri olduğunu gösterdi ( $p<0.05$, olasılık oranı 7.68, 3,23 sırasıyla).

Sonuç: Aspirasyon pnömonisi olan geriatrik hastaların yoğun bakım ünitesine yatışlarında ilk 28 günlük mortaliteyi öngörmede birçok değişken anlamlı olmakla birlikte, HCA-AP varlığı, yüksek yatış APAÇHE II skoru ve düşük GCS skoru anlamlı bağımsız değişkenlerdi.

Anahtar Kelimeler: Aspirasyon pnömonisi, geriatri, mortalite öngörücüleri, yoğun bakım üniteleri, sağlık hizmeti ilişkili aspirasyon pnömonisi

Corresponding (iletişim): Fulya Çiyiltepe, Department of Anesthesiology and Intensive Care, Health Sciences University Kartal Dr. Lutfi Kirdar City Hospital, Istanbul, Turkey

E-mail (E-posta): drfulyadanaci@hotmail.com

Received (Geliş Tarihi): 20.08.2021 Accepted (Kabul Tarihi): 08.10.2021 


\section{INTRODUCTION}

Caused by aspiration of colonized oropharyngeal secretions, aspiration pneumonia (AP) is one of the most important causes of intensive care hospitalization and high mortality, especially in elderly patients with neurological problems or those in nursing homes. ${ }^{[1-3]}$ Among geriatric patients, those over the age of 80 and referred to as very elderly patients need increasingly more follow-up in the intensive care unit (ICU), and in addition to multiple comorbidities associated with systemic diseases, dementia, frailty, difficulty in swallowing or in maintaining the airway contribute to the increase in $\mathrm{AP}^{[4,5]}$

AP is a clinical condition difficult to be diagnosed. It is defined as the history of witnessed aspiration, the presence of infiltration in the zones consistent with aspiration in lung imaging, and laboratory results consistent with infection in the elderly with oral dysphagia due to comorbid conditions. ${ }^{[6,7]}$

The diagnosis of AP that increases with age is also supported by various studies. In one study, dysphagia was detected at a rate of $15 \%$ in patients older than 65 years, and in another one, AP was found almost six times more in patients older than 75 years of age compared to those aged $60 .{ }^{[4,8]}$ In another study, a water swallow test was conducted on 134 patients with a mean age of 84 who were hospitalized for pneumonia, and oropharyngeal dysphagia was reported with a rate of $55 \%{ }^{[9]}$

In AP, it is necessary to estimate the bacteriological agent and to arrange a treatment based on the severity of the disease. Therefore, while estimating the source of $\mathrm{AP}$, it is of importance to determine whether it is community-acquired aspiration pneumonia (CA-AP) or healthcare-associated aspiration pneumonia (HCA-AP). In general, 7-10 days of treatment is sufficient in CA-AP patients who come from home and do not have a history of recent hospitalization and antibiotic use while long-term treatment (14-21 days, up to weeks or months) is required in complicated cases such as necrotizing pneumonia or lung abscess. ${ }^{[10,11]}$

Mortality rates ranging from $0 \%$ to $85 \%$ due to AP have been reported in the literature, and this rate increases with age in very elderly patients..$^{[12]}$

The aim of this study is to reveal the demographic and clinical parameters that affect the treatment results and mortality in the very elderly patient group hospitalized due to AP in the ICU in our clinic.

\section{MATERIAL AND METHOD}

The study was conducted by following the ethical principles stated in the Declaration of Helsinki, "Good Medical Practice Guidelines" and "Good Laboratory Practice Guidelines". The study was carried out with the permission of Haydarpasa Numune Training and Research Hospital Ethics Committee (Date: 06.09.2021, Decision No: E-62977267-000-11783).

The data of the patients who were followed up in the Level 3 ICU for 5 years were reviewed retrospectively, and out of the very elderly patients over the age of 80 who were admitted to the ICU from the emergency department with the diagnosis of AP for the first time, a total of 221 whose data could be accessed were included in the study. They were divided into two groups according to the 28-day outcome (survivorsnonsurvivors). Group 1 represents the survivor group while Group 2 represents the group with intensive care mortality.

The diagnosis of AP was made according to the following clinical criteria: ${ }^{[6,13]}$

- Presence of newly emerging infiltration in a location consistent with aspiration in lung imaging (lung radiography or tomography),

- Presence of at least one of the major criteria (cough, sputum, chills-shivering-fever) or at least two of the minor criteria (dyspnea, pleuritic chest pain, change in consciousness, auscultation findings consistent with consolidation in physical examination, high or low white blood cell in the hemogram control $>12.000 / \mathrm{mm}^{3}$ or $<4000 / \mathrm{mm}^{3}$ ) for the diagnosis of pneumonia,

- History of witnessed aspiration or ongoing dysphagia, or presence of aspiration symptoms such as coughing, bruising, and dyspnea after each intake.

The admission levels of arterial blood $\mathrm{pH}$ (power of Hydrogen) and $\mathrm{pCO}_{2}$ (Partial pressure of carbon dioxide) and lactate, Blood Urea Nitrogen (BUN), creatinine, potassium (K) and sodium ( $\mathrm{Na}$ ) levels, Acute Physiology and Chronic Health Evaluation (APACHE) score, Glasgow Coma Scale (GCS) score, modified shock index (MSI) and the aspiration pneumonia's source ( community-acquired aspiration pneumonia (CA-AP) or healthcare-associated aspiration pneumonia (HCA-AP)) were recorded.

When evaluating aspiration pneumonia according to its source, the definitions in the guidelines related to pneumonia were taken into account. Community-acquired pneumonia (CAP) is an acute infection of the pulmonary parenchyma in a patient who has acquired the infection in the community while healthcare-associated pneumonia (HCAP) is an infection that is closely associated with acute care hospitals or observed in inpatients of chronic care institutions, and it is mostly caused by multi-drug-resistant bacteria. ${ }^{[14,15]}$ Hospital Acquired Pneumonia (HAP) is defined as pneumonia that occurs at least 48 hours after admission to the hospital, or that is not in the incubation period at the time of admission or develops 48 hours after discharge from the hospital. ${ }^{[14]}$ Therefore, the patients who fell under this definition were excluded from the study as they had transient hospital flora, the duration of their treatment before intensive care varied and due to difficulties in diagnosing.

Among the variables between Group 1 and Group 2, those that had an effect on 28-day intensive care mortality were determined, and cut-off values for these markers were given.

\section{Statistical Analysis}

In the statistical analysis of the findings obtained in the study, IBM SPSS Statistics 22 (IBM SPSS, Turkey) software 
was used. The conformity of the parameters to the normal distribution was evaluated via the Shapiro-Wilks test, which showed that the parameters were normally distributed. While analyzing the study data, descriptive statistical methods (mean, standard deviation, median, frequency) were used and independent samples T-test was used to compare the quantitative data. Pearson Chi-Square test was used to compare the qualitative data. Binary logistic regression analysis was performed for the data found significant in the univariate analyses and independent risk factors were determined to show mortality. ROC curves were prepared for the significant quantitative data, and sensitivity and specificity were calculated. Significance was evaluated at $p<0.05$.

\section{RESULT}

A total of 221 patients with a mean age of 85.0 years who were diagnosed with AP and followed in the ICU were included in the study (Table 1). The patients were divided into two groups according to the presence of 28-day intensive care mortality-106 patients were discharged from the ICU, and 115 patients died. There was no difference between the groups in terms of demographic data and comorbid diseases (Table 1). While $53.8 \%$ of the patients had HCA-AP, $46.2 \%$ had CA-AP.

HCA-AP was significantly higher in the mortality group and was an independent risk factor that increased mortality 2.6fold (Odds ratio: $0.374,95 \% \mathrm{Cl} 0.186-0.753, \mathrm{p}: 0.006$ ) ( Table 2). Mortality was $66.3 \%$ in 119 patients with HCA-AP and this rate was $35.2 \%$ in 102 patients with CA-AP.

\begin{tabular}{|c|c|c|c|c|}
\hline & $\begin{array}{c}\text { Mortality (-) } \\
\text { n:106 }\end{array}$ & $\begin{array}{c}\text { Mortality (+) } \\
\text { n:115 }\end{array}$ & Univariate & Multivariate \\
\hline Age & $84.46 \pm 3.96$ & $85.50 \pm 4.62$ & $0.08 a$ & \\
\hline $\begin{array}{l}\text { Gender } \\
\text { Female } \\
\text { Male }\end{array}$ & $\begin{array}{l}67(\% 63.2) \\
39(\% 36.8)\end{array}$ & $\begin{array}{l}73(\% 63.5) \\
42(\% 36.5)\end{array}$ & $0.54 b$ & \\
\hline $\begin{array}{l}\text { Comorbid } \\
\text { diseases }\end{array}$ & $38(\% 35.8)$ & 38 (\%33.0) & $0.72 a$ & \\
\hline $\begin{array}{l}\text { HCA-AP } \\
\text { CA-AP }\end{array}$ & $\begin{array}{l}40(\% 37.7) \\
66(\% 62.3)\end{array}$ & $\begin{array}{l}79(\% 68.7) \\
36(\% 31.3)\end{array}$ & $0.00 a$ & $0.006 c$ \\
\hline APACHE II & $19.96 \pm 6.67$ & $28.03 \pm 6.06$ & $0.00 \mathrm{~b}$ & $0.000 c$ \\
\hline GCS & $12.42 \pm 3.10$ & $9.32 \pm 4.01$ & $0.00 \mathrm{~b}$ & $0.003 c$ \\
\hline SI & $0.21 \pm 0.41$ & $0.55 \pm 0.72$ & $0.00 \mathrm{~b}$ & $0.206 c$ \\
\hline MSI & $0.72 \pm 0.61$ & $1.00 \pm 0.84$ & $0.01 b$ & $0.415 c$ \\
\hline BUN & $53.05 \pm 36.22$ & $62.18 \pm 34.67$ & $0.05 b$ & $0.787 c$ \\
\hline Creatinine & $1.54 \pm 1.69$ & $1.80 \pm 2.08$ & $0.42 b$ & \\
\hline Sodium & $138.75 \pm 7.16$ & $142.22 \pm 11.38$ & $0.00 \mathrm{~b}$ & $0.961 c$ \\
\hline Glucose & $162.27 \pm 107.28$ & $151.87 \pm 80.68$ & $0.41 b$ & \\
\hline Potassium & $3.79 \pm 0.88$ & $3.94 \pm 1.01$ & $0.23 b$ & \\
\hline $\mathrm{pH}$ & $7.00 \pm 0.10$ & $6.96 \pm 0.18$ & $0.05 b$ & $0.999 c$ \\
\hline $\mathrm{pCO}_{2}$ & $40.89 \pm 23.46$ & $42.43 \pm 26.8$ & $0.67 b$ & \\
\hline Lactate & $2.23 \pm 5.60$ & $3.10 \pm 3.47$ & $0.17 b$ & \\
\hline \multicolumn{5}{|c|}{$\begin{array}{l}\text { aPearsonChi-square, bT-Test, cBinarylogistic, p<0.05 statisticallysignificant, DM: DiabetesMellitus, } \\
\text { HCA-AP: Healthcare-associated aspiration pneumonia, CA-AP: Community-acquired aspiration } \\
\text { pneumonia, APACHE II: Acute Physiology and Chronic Health Evaluation, GCS: Glasgow Coma Scale, } \\
\text { SI: Shock Index, MSI: ModifiedShock Index, BUN: Blood Urea Nitrogen, pH: power of Hydrogen, pCOz: } \\
\text { Partial pressure of carbon dioxide }\end{array}$} \\
\hline
\end{tabular}

Table 2. Binary logistic regresion analysis for the factors affecting mortality

\begin{tabular}{lcccc} 
& \multirow{2}{*}{ Sig. } & \multirow{2}{*}{ Odds Ratio } & \multicolumn{2}{c}{$\mathbf{9 5 , 0 \%}$ C.I. } \\
\cline { 4 - 5 } & & & Lower & Upper \\
\hline HCA-AP & 0.006 & 0.374 & 0.186 & 0.753 \\
APACHE II & 0.000 & 1.162 & 1.093 & 1.235 \\
GCS & 0.003 & 0.862 & 0.782 & 0.951 \\
\hline
\end{tabular}

HCA-AP: Healthcare-associated aspiration pneumonia, APACHE II: Acute Physiology and Chronic Health Evaluation, GCS: Glasgow Coma Scale

APACHEIl scores were significantly higher in the mortality group and were an independent risk factor for indicating mortality (OR: 1.16, \%95 Cl 1,093-1,235, p:0,00) (Table 2). In the ROC analysis, mortality was observed in the patients with APACHEII $>22.5$ with a sensitivity of $81.7 \%$ and a specificity of $32.1 \%$ (Figure 1, Table 3).

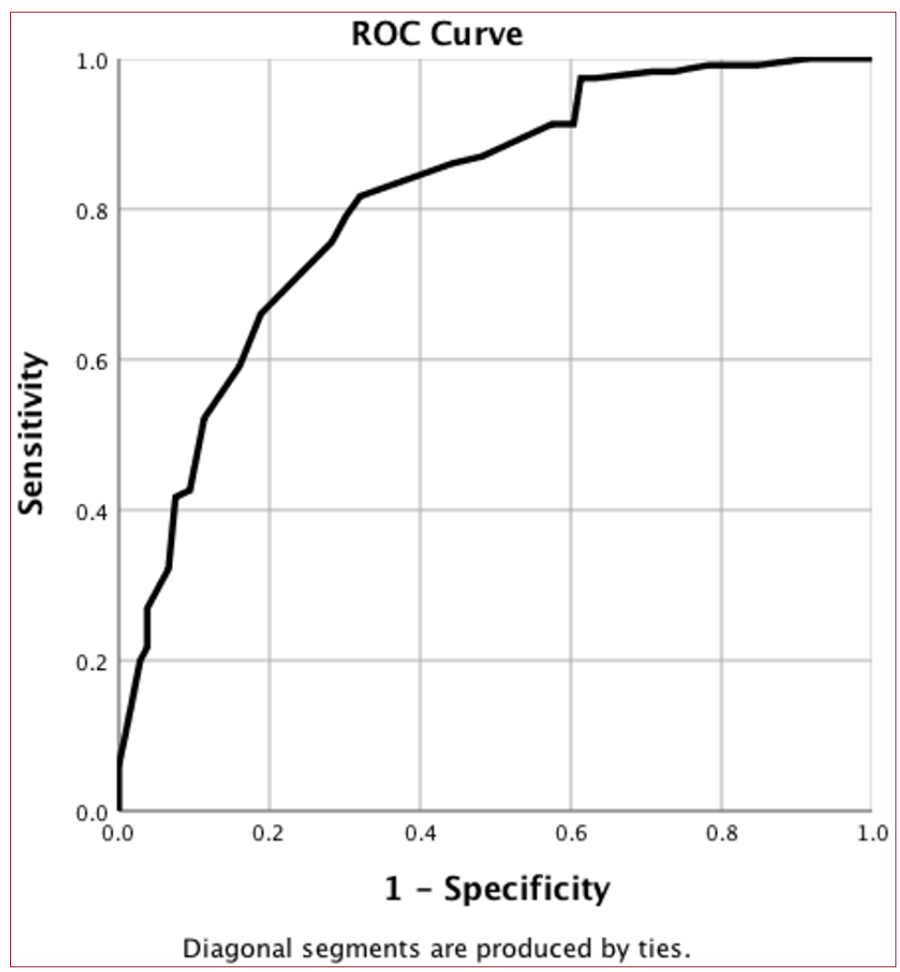

Figure 1. ROC curvesfor APACHEII

In the analyses performed, it was observed that the GCS was significantly lower in the mortality group and each unit decrease in GCS increases mortality 1.16 times as an independent factor in showing mortality (Table 2). In the ROC analysis, mortality was expected in the patients with GCS $<9$ with a sensitivity of $82.1 \%$ and a specificity of $47.8 \%$ (Figure 2, Table 3).

$\mathrm{SI}, \mathrm{MSI}$ values, $\mathrm{Na}$ and BUN levels were found to be higher in the mortality group. And initial Ph levels were to be found lower in mortality group. However, when these parameters were included in the multivariate analysis, they were not found to be risk factors for predicting mortality.And the other laboratory markers we evaluated were similar between the two groups (Table 1). 


\begin{tabular}{lcccccc}
\hline Table 3. ROC analysis of APACHE II and GCS & & & & \\
Test Result Variable(s) & Area Under Curve (AUC) & Std. Errora & Asymptotic Sig.b & Value & Sensitivity \% & Specificity \% \\
\hline APACHEII & .812 & .029 & .000 & $>22.5$ & 81.7 & 32.1 \\
GCS & .730 & .034 & .000 & $<9$ & 82.1 & 47.8 \\
\hline
\end{tabular}

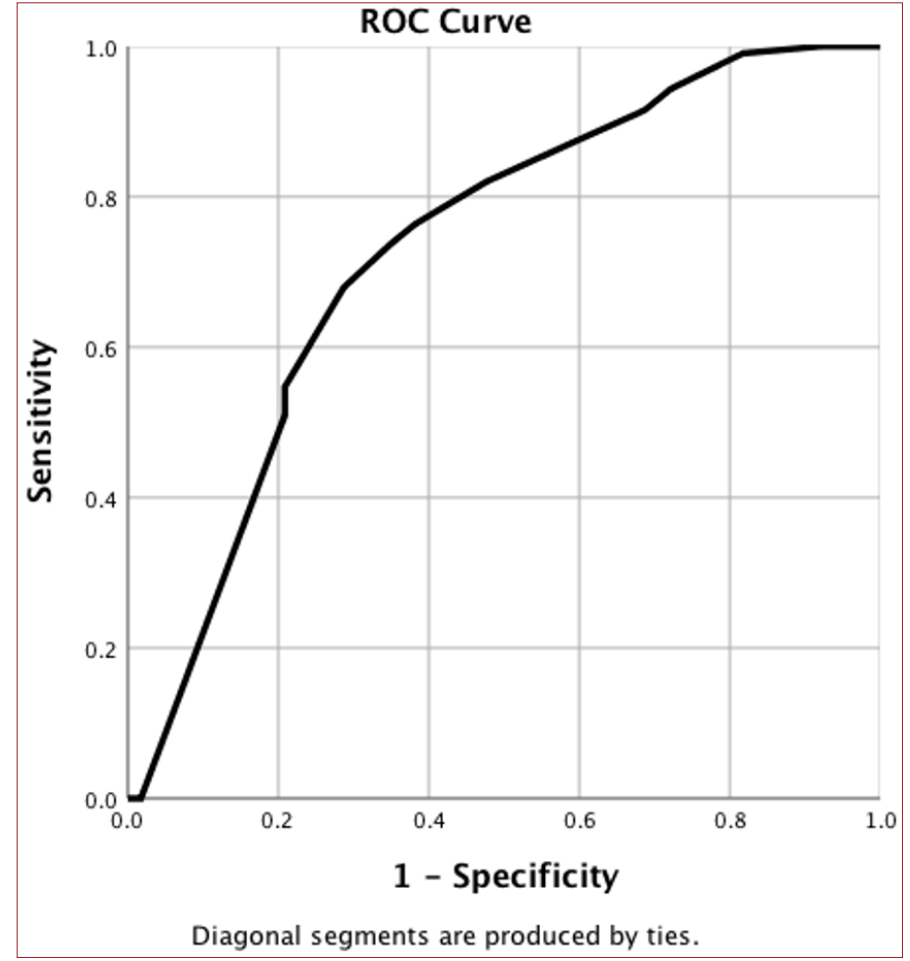

Figure 2. ROC curvesfor GCS

\section{DISCUSSION}

In this study, in which we examined 221 patients over 80 years of age who needed ICU follow-up due to AP and its effect on intensive care mortality, we found that the presence of HCA-AP, high hospitalization APACHE II score and low GCS score were significant independent variables in predicting intensive care mortality.

Studies related to AP have been done either in children or in the elderly. In studies conducted with elderly patients in parallel with ours, it was reported that the incidence in CAP was $15 \%$, while it was found to be $30 \%$ in HCAP. ${ }^{[16]}$ Similarly, Marik also stated in his study that AP accounted for $15 \%$ of CAPs, and this rate was lower than potential due to occult aspirations and difficulties in diagnosis. ${ }^{[17]}$ However, in a study in which 628 patients with AP were examined, it was reported that CA-AP was higher. ${ }^{[7]}$ In our study $53.8 \%$ of the patients had HCA-AP, 46.2\% had CA-AP.

Although the varying rates in AP-related mortality draw attention, generally AP has higher mortality compared to isolated CAP. Lanspa et al. ${ }^{[7]}$ also revealed in their study that the rates of hospitalization and intensive care hospitalization due to $A P$ with all reasons (HCA-AP+ CA-AP) were higher than those due to isolated CAP, regardless of the source (99\% vs. $58 \% ; n=628$ and $38 \%$ vs. $14 \%$, respectively). Attention is drawn to the fragile features of AP patients and the severity of the causative disease.

The source of AP also has a significant effect on mortality. For example, while the 30 -day mortality rate was found $21 \%$ in a study in which CA-AP was more intense, there are also studies with higher mortality rates reaching up to $65 \% .^{[7,18,19]}$ The high mortality rates were attributed to the aspirated oropharyngeal colonization being composed of different microorganisms (especially gram-negative bacilli and anaerobic organisms) and the association of AP with the underlying fragile disease. More resistant microorganisms were detected, especially in those with HCA-AP. ${ }^{[18,19]}$ In our study, the total intensive care mortality rate due to AP was $52 \%$ while it was $66.4 \%$ in HCA-AP and $35.2 \%$ in CA-AP.

In a study examining 95 elderly patients diagnosed with $A P$ who had been living in a nursing home for a long time (HCA-AP), mortality was found to be $36 \%$.This rate was found to be almost 1.5 times higher in our study. However, our study is different in that all of our patients consisted of severe cases requiring ICU follow-up, and that is why we think our mortality rate was higher in HCA-AP. Unlike our study, hospitalization APACHE II score was not shown as an independent mortality indicator in this study. ${ }^{[19]}$

There are studies showing that high APACHE II score is associated with mortality in medical ICUs. ${ }^{[20]}$ In a study examining pneumonia-related ICU follow-up, the APACHE II score, which was predicted as a mortality indicator, was reported as 29.8. ${ }^{[21]}$ In our study, an APACHE II score > 22.5 was an independent variable in predicting mortality. The lower APACHE II score in our study was attributed to the older age of our patient group.

Although a low GCS score is associated with the inability to protect the airway, the risk of aspiration and the need for intubation, the opposite is also argued. ${ }^{[22-24]}$ The relationship between GCS and mortality has been studied mostly in trauma groups and has been associated with traumatic neurological deficit. However, there are not enough studies examining the relationship between aging-related neurological deficit and decrease in airway reflexes and GCS. In our study, we found that a GCS score $<8$ during ICU admission was an independent variable in determining mortality in very elderly patients with AP.

Shock index and MSI are used as mortality indicators in medical ICU in recent studies. Namita et al. found that increases in the MSI cut-off point >1.3 were associated with ICU mortality in early septic shock. ${ }^{[25]}$ Özgültekin et al. conducted a study with an elderly age group (>65) and found that the higher the rate the MSI value the more the mortality rate in medical ICU (the cut-off point $\mathrm{O}$ the 
modified shock index is $>1.4$, which has a sensitivity of $47.1 \%$ and a specificity of $80.9 \%) .{ }^{[26]}$ In our study, The MSI value in very elderly patient group with AP that not show any predictive value for ICU mortality.

Hypernatremia is one of the most common electrolyte abnormalities in elderly patients and is associated with a high mortality rate. ${ }^{[27]} \mathrm{A}$ study showed that pneumonia patients over 80 years of age with higher Na levels and worse renal function had higher mortality. ${ }^{[28]}$ Similarly, high $\mathrm{Na}$ and BUN and low pH values were found to be associated with mortality in the univariate analysis but not as independent prognostic factors of mortality in our study.

There are limitations to our study. the study was planned retrospectively and that an analysis could not be made according to the bacteriological agent. Therefore, we could not determine the microbiological factor for the etiology of CA-AP and HCA-AP. However, the unique aspect of our study is that all of our patients were over the age of 80 and admitted to the ICU with the diagnosis of AP.

\section{CONCLUSION}

Our results indicate that HCA-AP, APACHE II and GCS are the strongest independent indicators of mortality of geriatric patients with AP in the first 28 days.

\section{ETHICAL DECLARATIONS}

Ethics Committee Approval: The study was carried out with the permission of Haydarpasa Numune Training and Research Hospital Ethics Committee (Date: 06.09.2021, Decision No: E-62977267-000-11783).

Informed Consent: All patients signed the free and informed consent form.

\section{Referee Evaluation Process: Externally peer-reviewed.}

Conflict of Interest Statement: The authors have no conflicts of interest to declare.

Financial Disclosure: The authors declared that this study has received no financial support.

Author Contributions: All of the authors declare that they have all participated in the design, execution, and analysis of the paper, and that they have approved the final version.

Note: This study was presented as poster in INEREM 2015 and National Physical Medicine and Rehabilitation Congress 2015.

\section{REFERENCES}

1. Torres A, Serra-Batlles J, Ferrer Aet al. Severe community-acquired pneumonia. Epidemiology and prognostic factors. Am Rev Respir Dis 1991;144(2):312-8.

2. Teramoto S. Clinical Significance of Aspiration Pneumonia and Diffuse Aspiration Bronchiolitis in the Elderly. J Gerontol Geriatr Res 2013;03(01).

3. Luk JK, Chan DK. Preventing aspiration pneumonia in older people: do we have the 'know-how'? Hong Kong Med J 2014;20(5):421-7.
4. Mitchell SL, Kiely DK, Lipsitz LA. The Risk Factors and Impact on Survival of Feeding Tube Placement in Nursing Home Residents With Severe Cognitive Impairment. Arch Intern Med 1997;157(3):327-32.

5. Ding $X$, Lian $H$,Wang $X$. Management of Very Old Patients in Intensive Care Units. Aging Dis 2021;12(2):614-24.

6. Komiya K, Ishii H, Kadota J. Health care-associated Pneumonia and Aspiration Pneumonia. Aging Dis 2014;6(1):27-37.

7. Lanspa MJ, Jones BE, Brown SM, Dean NC. Mortality, morbidity, and disease severity of patients with aspiration pneumonia. J Hosp Med 2013;8(2):83-90.

8. Kaplan V, Angus DC, Griffin MF, Clermont G, Scott Watson R, Linde-Zwirble WT. Hospitalized community-acquired pneumonia in the elderly: ageand sex-related patterns of care and outcome in the United States. Am J Respir Crit Care Med 2002;165(6):766-72.

9. Cabre M, Serra-Prat M, Palomera E, Almirall J, Pallares R, Clavé P. Prevalence and prognostic implications of dysphagia in elderly patients with pneumonia. Age Ageing 2010;39(1):39-45.

10. Lode $\mathrm{H}$. Microbiological and clinical aspects of aspiration pneumonia. $J$ Antimicrob Chemother 1988;21:83-90.

11. Ott SR, Lode H. [Diagnosisandtherapy of aspirationpneumonia]. DtschMedWochenschr. 2006;131(12):624-8.

12. Hickling KG, Howard R. A retrospective survey of treatment and mortality in aspiration pneumonia. Intensive Care Med. 1988;14(6):617-22.

13. Janda M, Scheeren TW, Nöldge-Schomburg GF. Management of pulmonaryaspiration. Best Pract Res Clin Anaesthesiol 2006;20(3):409-27.

14. American Thoracic Society; Infectious Diseases Society of America Guidelines for the management of adults with hospital-acquired, ventilator-associated, and health care-associated pneumonia. Am J Respir Crit Care Med. 2005;171(4):388-416.

15. Metlay JP, Waterer GW, Long AC, et al. Diagnosisand treatment of adults with community-acquired Pneumonia. An official clinical practice guideline of the American Thoracic Society and Infectious Diseases Society of America. Am J Respir Crit Care Med 2019; 200:e45.

16. Komiya K, Ishii H, Kadota J. Healthcare-associated Pneumonia and Aspiration Pneumonia. Aging Dis. 2014;6(1):27-37.

17. Marik PE. Aspiration pneumonitis and aspiration pneumonia. N Engl J Med. 2001;344(9):665-71.

18. Pikus L, Levine MS, Yang YX, et al. Video fluoroscopic studies of swallowing dysfunction and the relative risk of pneumonia. Am J Roentgenol. 2003;180:1613-6.

19. El-Solh AA, Pietrantoni C, Bhat A, et al. Microbiology of severe aspiration pneumonia in institutionalized elderly. Am J Respir Crit Care Med. 2003;167(12):1650-4.

20. Godinjak A, Iglica A, Rama A, et al. Predictivevalue of SAPS II and APACHE II scoring systems for patient outcome in a medical intensive care unit. Acta Med Acad. 2016;45(2):97-103.

21. Altas OF, Kizilkaya M. The Effects of Neutrophil-Lymphocyte Ratio, PlateletLymphocyte Ratio and Prognostic Markers in Determining the Mortality in Patients Diagnosed With Pneumonia in Intensive Care. Medeni Med J. 2021;36(2):130-7.

22. Eizadi-Mood N, Saghaei M, Alfred S, et al. Comparative evaluation of Glasgow coma score and gag reflex in predicting aspiration pneumonitis in acute poisoning. J Crit Care 2009;24:470.e9-470.15.

23. Montassier E, Le Conte P. Aspiration pneumonia and severe selfpoisoning: about the necessity of early airway management. J Emerg Med. 2012;43:122-3.

24. Abdallah A, Demaerschalk BM, Kimweri D, et al. A comparison of the Full Outline of Unresponsiveness (FOUR) and Glasgow ComaScale (GCS) scores in predicting mortality among patients with reduced level of consciousness in Uganda. Neurocrit Care. 2020;32(3):734-41.

25. Jayaprakash N, Gajic O, Frank RD, Smischney N. Elevated modified shock index in early sepsis is associated with myocardial dysfunction and mortality. J CritCare. 2018;43:30-5. 
26. Özgültekin A, Çiyiltepe F. Do shock index and modified shock index have any prognostic value in severely ill elderly, medical patients with multiple comorbidities? Int J Gerontol 2019;13:76-80

27. Schlanger LE, Bailey JL, Sands JM. Electrolytes in theaging. Adv Chronic Kidney Dis. 2010;17(4):308-19.

28. Pinargote H, Ramos JM, Zurita A, Portilla J. Clinical features and outcomes of aspiration pneumonia and non-aspiration pneumonia in octogenarians and nonagenarians admitted in a General Internal Medicine Unit. Rev Esp Quimioter. 2015;28(6):310-3. 